\title{
KEMAMPUAN KOMUNIKASI MATEMATIS SISWA DALAM MENYELESAIKAN SOAL GEOMETRI KUBUS DAN BALOK
}

\author{
Norma Nur Hikmawati ${ }^{1}$ Novi Andri Nurcahyono ${ }^{2}$ dan Pujia Siti Balkist ${ }^{3}$ \\ 1,2,3 (Pendidikan Matematika, Universitas Muhammadiyah Sukabumi) \\ normanurhikmawati@gmail.com
}

\begin{abstract}
ABSTRAK
Penelitian ini bertujuan untuk mendeskripsikan kemampuan komunikasi matematis tertulis siswa dalam menyelesaikan soal geometri kubus dan balok serta untuk menemukan faktor-faktor yang mempengaruhi kemampuan komunikasi matematis. Penelitian ini merupakan penelitian kualitatif dengan jenis penelitian yang digunakan adalah deskriptif. Penentuan subjek penelitian dilakukan secara purposive sampling dengan memilih 2 siswa dari setiap kategori hasil tes dengan kemampuan tinggi, sedang dan rendah. Analisis data melalui tiga langkah yaitu reduksi data, penyajian data dan penarikan kesimpulan. Hasil penelitian menunjukkan bahwa subjek dengan kemampuan tinggi telah memenuhi semua aspek kemampuan komunikasi matematis, yaitu aspek menulis, menggambar dan ekspresi matematika. Subjek dengan kemampuan sedang dan rendah dominan pada aspek menulis dan menggambar dan kesulitan untuk mengekpresikan ide-ide matematisnya ke dalam aspek ekspresi matematika. Faktor-faktor yang diduga mempengaruhi kemampuan komunikasi matematis yaitu proses pembelajaran, sikap dan pemahaman siswa, serta pembiasaan pemberian latihan soal.
\end{abstract}

Kata Kunci : komunikasi matematis, aspek komunikasi matematis, geometri

\section{ABSTRACT}

This research aims to describe the written mathematical communication skills in solving geometry problems of cubes and beams, and to find factors that influence mathematical communication skills of stdudents. This research used deskriptive qualitative approach. The six students were selected by purposive sampling from each category of test result comprised of high, middle and low ability. The data analyzed by three steps there are reduction, data display and conclusion. The result showed that students with high ability had fulfilled all aspects of mathematical communication skills, namely writing, drawing and mathematical expression. Both students with middle and low ability are dominant in writing and drawing, yet difficult to express mathematical ideas into mathematical expression. The influence factors of mathematical communication skills included of learning process, attitude and understanding, and habituation of giving practice questions.

Keywords: mathematical communication, aspects of mathematical communication, geometry

\section{PENDAHULUAN}

Matematika merupakan salah satu mata pelajaran yang diajarkan pada setiap jenjang pendidikan. Demikian pentingnya matematika Rosdiana (2018) mengatakan bahwa matematika mampu membekali siswa untuk memiliki kemampuan berpikir sistematis, logis dan analitis sehingga membantu siswa dalam melakukan penyelesaian masalah sehari-hari. Lerner (Hermawati, 2018) mengemukakan bahwa matematika adalah bahasa simbolis dan universal yang memungkinkan manusia untuk memikirkan dan 
mengkomunikasikan ide mengenai elemen dan kuantitas. Kemampuan siswa dalam mengemukakan ide-ide matematis kepada orang lain secara lisan maupun tulisan dinamakan kemampuan komunikasi matematis (Lestari dan Yudhanegara, 2018). Komunikasi secara lisan dapat berupa diskusi, bertanya hingga penjelasan konsep dan strategi penyelesaian suatu masalah. Sedangkan komunikasi matematis secara tulisan, ide matematika dapat diungkapkan melalui simbol-simbol ilmiah seperti gambar, diagram, grafik persamaan matematika, ataupun notasi matematika lainnya (Hodiyanto, 2017).

Kemampuan komunikasi matematis sangatlah diperlukan dalam pembelajaran matematika, seperti dikemukakan oleh Asikin (Hendriana, 2017), ada beberapa peran komunikasi dalam pembelajaran matematika, yaitu membantu mempertajam cara berpikir siswa serta sebagai alat untuk mengukur kemampuan pemahaman dan merefleksi pemahaman matematika siswa. Pentingnya kemampuan komunikasi matematis juga diungkapkan oleh Hendriana (2017) bahwa komunikasi matematis merupakan suatu kemampuan dasar matematis yang esensial dan perlu dimiliki oleh setiap siswa sekolah menengah. Selain itu, Baroody (Hendriana, 2017) memperkuat bahwa komunikasi matematis digunakan dalam beragam konten matematika juga sebagai modal dalam menyelesaikan dan mengkonstruksi matematik serta sebagai sarana bertukar pendapat dan pikiran antar siswa.

Namun pada kenyataannya hasil penelitian munawaroh (2018) menunjukkan bahwa kemampuan komunikasi matematis siswa secara lisan maupun tertulis saat ini masih tergolong rendah. Fakta dilapangan juga membuktikan bahwa ide matematis siswa belum tersampaikan dengan baik ketika dihadapkan pada suatu permasalahan matematika, khususnya pada soal yang berhubungan dengan gambar dan penggunaan simbol atau model matematika termasuk di dalamnya adalah materi geometri. Shalihah dan Afriansyah (2017) mengatakan bahwa "Tujuan pembelajaran geometri adalah agar siswa memperoleh rasa percaya diri mengenai kemampuan matematikanya, menjadi pemecah masalah yang baik dan dapat berkomunikasi secara matematik". Berdasarkan penjelasan tersebut, setidaknya kemampuan komunikasi matematis perlu dimiliki siswa untuk menyelesaikan soal geometri, dalam hal ini bangun ruang sisi datar. Oleh karena itu, perlu dilakukan penelitian tentang sejauh mana kemampuan komunikasi matematis siswa dalam menyelesaikan soal pada materi geometri bangun ruang sisi datar kubus dan balok.

Adapun indikator yang digunakan dalam penelitian ini mengacu pada indikator yang dikemukakan oleh Kementerian Pendidikan Ontario dan NCTM sebagai berikut. 
Tabel 1. Indikator Kemampuan Komunikasi Matematis

\begin{tabular}{|c|c|c|}
\hline Aspek & & Deskripsi \\
\hline Written Text & a. & Mengidentifikasi informasi yang diketahui dalam soal. \\
\hline Menjelaskan ide, & b. & Mengidentifikasi hal yang ditanyakan dalam soal. \\
\hline $\begin{array}{l}\text { situasi, dan relasi } \\
\text { matematika secara }\end{array}$ & c. & $\begin{array}{l}\text { Menuliskan ide strategi penyelesaian menggunakan bahasa } \\
\text { sendiri dengan tepat dan dapat dipahami. }\end{array}$ \\
\hline tulisan. & d. & Dapat menjelaskan ide menggunakan istilah matematika. \\
\hline Drawing & a. & Menyajikan situasi, ide atau solusi dari permasalahan \\
\hline Menjelaskan ide & & matematika dalam bentuk gambar dengan tepat. \\
\hline matematika dalam & b. & Menyajikan situasi, ide atau solusi dari permasalahan \\
\hline $\begin{array}{l}\text { bentuk visual (gambar, } \\
\text { tabel atau diagram) }\end{array}$ & & matematika dalam bentuk gambar dengan jelas \\
\hline Mathematical Ekspression & a. & Dapat menyajikan ide dan situasi menggunakan model \\
\hline Menjelaskan ide, situasi & & matematika dengan benar dan lengkap. \\
\hline $\begin{array}{l}\text { masalah gambar atau } \\
\text { benda nyata ke dalam }\end{array}$ & b. & $\begin{array}{l}\text { Dapat menyajikan ide menggunakan bahasa simbol/notasi } \\
\text { matematika dengan benar. }\end{array}$ \\
\hline bahasa simbol, model & c. & Menggunakan semua informasi yang ada pada masalah \\
\hline matematika. & d. & Menarik kesimpulan dengan tepat. \\
\hline
\end{tabular}

Tujuan penelitian ini adalah: 1) untuk mengetahui kemampuan komunikasi matematis siswa dalam menyelesaikan soal geometri kubus dan balok dan 2) untuk mengetahui faktor-faktor yang mempengaruhi kemampuan komunikasi matematis.

\section{METODOLOGI PENELITIAN}

Penelitian ini merupakan penelitian dengan pendekatan deskriptif kualitatif. yaitu jenis penelitian yang digunakan untuk membuat deskripsi secara sistematis, faktual, dan akurat mengenai fakta-fakta, dan sifat-sifat populasi daerah tertentu (Suryana, 2010). Deskripsi tersebut berbentuk kata-kata dan tidak menekankan pada angka. Dalam hal ini peneliti mendeskripsikan kemampuan komunikasi matematis tertulis siswa dalam menyelesaikan soal geometri kubus dan balok serta faktor-faktor yang diduga mempengaruhi kemampuan komunikasi matematis.

Penelitian dilakukan pada 30 siswa kelas VIII tahun ajaran 2018-2019. Penentuan sampel atau sumber data dilakukan secara purposive sampling, yaitu dipilih dengan pertimbangan dan tujuan tertentu (Sugiyono, 2016). Peneliti menetapkan 2 siswa dari setiap kategori hasil tes dengan kemampuan tinggi, sedang dan rendah, sehingga dalam penelitian ini subjek penelitian adalah 6 orang siswa sebagai fokus penelitian. Adapun 2 
subjek dari kategori kemampuan tinggi diberi kode T1 dan T2, subjek dengan kemampuan sedang adalah S1 dan S2, sedangkan subjek dengan kemampuan rendah diberi kode R1 dan R2.

Pengumpulan data dilakukan dengan teknik tes dan non tes, sehingga selain peneliti sebagai kunci instrumen penelitian, digunakan beberapa instrumen bantu untuk menunjang perolehan data yaitu pedoman wawancara, lembar observasi dan lembar tes kemampuan komunikasi matematis. Pemberian tes dilakukan sebanyak tiga siklus pada waktu yang berbeda guna memperoleh data yang jenuh mengenai kemampuan komunikasi matematis siswa. Terdapat 3 butir soal yang berbeda pada setiap tes tetapi masing-masing butir soal memuat beberapa aspek komunikasi matematis. Analisis data yang digunakan dalam penelitian ini adalah langkah-langkah analisis data yang dikemukakan oleh Miles \& Huberman (Sugiyono, 2016) yaitu reduksi data, penyajian data dan penarikan kesimpulan.

\section{HASIL DAN PEMBAHASAN}

Berdasarkan hasil analisis jawaban siswa meliputi 3 aspek kemampuan komunikasi matematis yaitu aspek menulis (Written Text), menggambar (Drawing) dan ekspresi matematika (Mathematical Expression) dapat teramati bahwa subjek dengan kemampuan tinggi mampu memenuhi ketiga aspek komunikasi matematis, sedangkan subjek dengan kemampuan sedang dan rendah rata-rata subjek hanya dominan pada aspek menulis dan menggambar. Berikut ini adalah diagram persentase kemampuan komunikasi matematis yang meliputi 3 aspek.

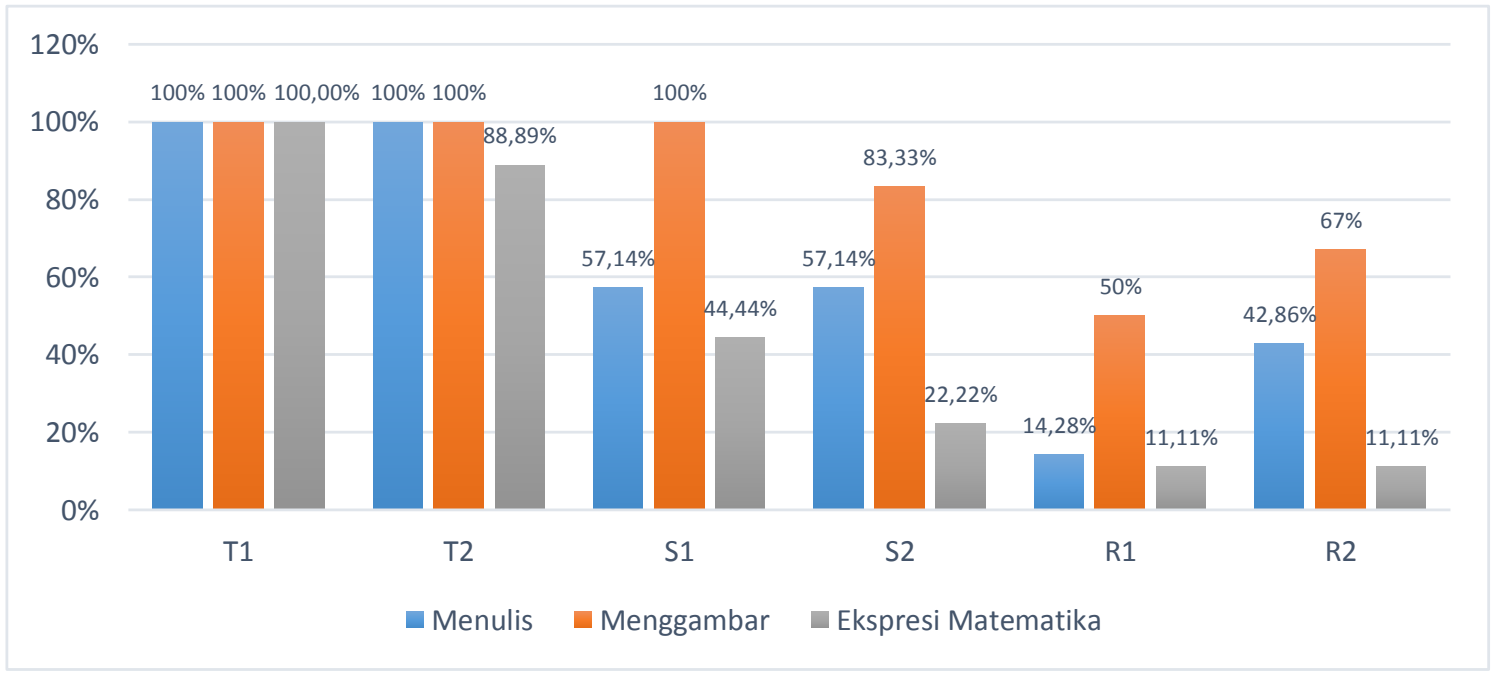

Gambar 1. Diagram Persentase Kemampuan Komunikasi Matematis Siswa 


\section{Aspek Menulis (Written Text)}

Kemampuan komunikasi matematis tertulis siswa berkemampuan tinggi yaitu T1 dan T2 dalam aspek menulis dapat diamati dengan baik. Subjek dengan kemampuan tinggi memperoleh persentase $100 \%$ dalam aspek menulis artinya subjek telah memenuhi aspek menulis pada setiap butir soal di setiap siklus tes. Subjek mampu menjelaskan ide, situasi dan relasi matematika secara tertulis dengan baik, hal tersebut terlihat dari kemampuan subjek dalam mengeidentifikasi dan menuliskan secara lengkap informasi yang diketahui dan ditanyakan dalam soal, serta mampu mengkomunikasikan ide dan gagasan yang dimilikinya untuk menyelesaikan permasalahan secara tertulis kepada orang lain dengan jelas dan dapat dipahami. Subjek dengan kemampuan sedang yaitu S1 dan S2 juga dapat memenuhi aspek menulis pada beberapa soal. Keterampilan menulis siswa dengan kemampuan sedang dapat diamati dengan baik dalam mendahului jawabannya dengan menuliskan informasi-informasi yang diketahui dan ditanyakan dalam soal serta menjelaskan ide strategi yang ada dalam pikirannya melalui tulisan walaupun dengan bahasa dan penyampaian yang sangat singkat dan kurang terperinci. Sedangkan Subjek dengan kemampuan rendah hanya sedikit saja memenuhi aspek menulis dari beberapa soal.

Subjek hanya mampu menuliskan sebagian saja informasi yang diketahui dalam soal dan kesulitan dalam mengidentifikasi informasi pendukung lainnya. Selain itu subjek juga belum memperlihatkan keterampilan menulisnya dalam menjelaskan ide strategi atau solusi penyelesaian yang dimilikinya terkait dengan masalah yang disajikan dalam soal secara tertulis.

\section{Aspek Menggambar (Drawing)}

Subjek dengan kemampuan tinggi telah mampu menjelaskan ide atau solusi dari permasalahan matematika dalam bentuk visual dengan tepat dan jelas pada setiap butir soal dari setiap siklusnya. Sehingga dapat dikatakan bahwa subjek T1 dan T2 telah memenuhi aspek menggambar dengan sangat baik. Subjek dengan kemampuan sedang S1 telah mampu menjelaskan ide atau solusi dari permasalahan matematika dalam bentuk gambar dengan tepat dan jelas pada siklus pertama hingga siklus ketiga pada setiap butir soalnya. Begitu pula dengan subjek S2 yang mampu menyajikan ide nya ke dalam bentuk visual dengan tepat dan jelas pada sebagian besar soal. Sehingga dapat dikatakan bahwa S1 dan S2 juga telah memenuhi aspek menggambar dengan baik. Sedangkan pada aspek menggambar subjek dengan kemampuan rendah mampu menggambarkan atau menyatakan 
ide dan situasi permasalahan ke dalam bentuk visual dengan tepat dan jelas dengan persentase rata-rata $91.66 \%$.

\section{Aspek Ekspresi Matematika (Mathematical Expression)}

Pada aspek ekspresi matematika subjek T1 dan T2 mampu menangkap ide dan mengkomunikasikan ide yang dimilikinya terkait dengan situasi dan permasalahan yang ada ke dalam ide matematis dengan baik. Hal ini ditunjukkan dengan kemampuan subjek dalam menggunakan bahasa simbol dan model matematika untuk mengekspresikan ide dan solusinya terhadap permasalahan yang ada dengan pemahaman yang baik serta mampu menarik kesimpulan yang relevan dengan permasalahan. Sedangkan subjek dengan kemampuan sedang S1 dan S2 mampu mengkomunikasikan ide yang dimilikinya ke dalam bahasa simbol dan model matematika dengan persentase rata-rata $33.33 \%$ saja dari semua soal, hal ini terjadi karena subjek dengan kemampuan sedang belum menggunakan semua informasi dalam soal dengan pemahaman yang baik sehingga berpengaruh pada penyelesaian soal. Selain itu subjek dengan kemampuan sedang sering melewatkan penarikan kesimpulan pada akhir jawabannya.

Pada aspek ekpresi matematika subjek dengan kemampuan rendah yaitu R1 maupun R2 menunjukkan bahwa subjek belum memahami masalah dan belum mampu menangkap ide atau solusi yang tepat untuk menyelesaikan soal sehingga subjek belum bisa mengkomunikasikannya ke dalam notasi, simbol dan model matematika dengan benar. Adapun salah satu contoh jawaban tertulis subjek T1, S1 dan R1 pada tes kemampuan komunikasi matematis yang memuat aspek menulis dan ekspresi matematika dapat dilihat pada gambar dibawah ini.

\section{Soal 1}

Pak Tono akan mengecat bagian dalam dinding rumah berbentuk balok dengan ukuran panjang $24 \mathrm{~m}$, lebar $6 \mathrm{~m}$ dan tinggi $4 \mathrm{~m}$. Tiap $8 \mathrm{~m}^{2}$ luas dinding menghabiskan $1 / 2$ kaleng cat. Harga satu kaleng cat adalah Rp 50.000,-

a. Hitunglah berapa rupiah biaya yang harus dikeluarkan Pak Tono untuk mengecat dinding rumah nya!

b. Bagaimana kamu memperolehnya? Jelaskan jawaban mu! 


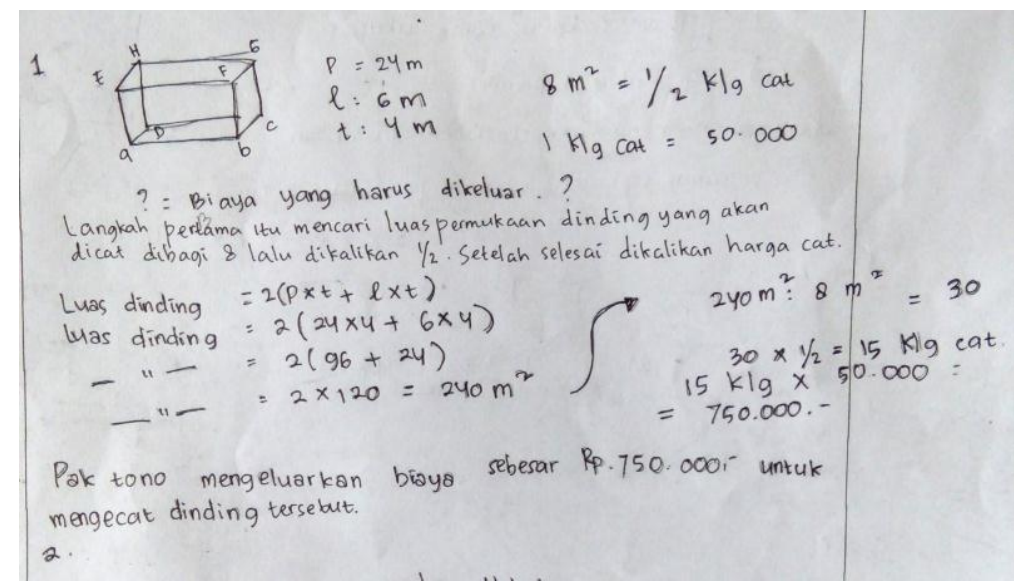

\section{Gambar 2. Jawaban T1 soal nomor 1}

Berdasarkan gambar 2 menunjukkan bahwa T1 mampu menjelaskan ide, situasi dan relasi matematika secara tulisan dengan baik, hal ini terlihat dari kemampuan subjek dalam mengidentifikasi informasi-informasi yang diketahui beserta hal yang ditanyakan dalam soal. Selain itu subjek mampu menjelaskan ide strategi yang dimilikinya secara tertulis terkait dengan permasalahan yang ada dengan penyampaian yang jelas dan dapat dipahami. Kesemuanya itu telah menunjukkan bahwa T1 telah memiliki keterampilan menulis yang baik. Sedangkan pada aspek ekspresi matematika subjek mampu mengkomunikasikan ide dan solusi yang dimilikinya ke dalam notasi/simbol dan model matematika dengan pemahaman yang baik, dalam hal ini subjek mampu menyusun model matematika yang tepat untuk mencari luas dinding yang akan di cat.

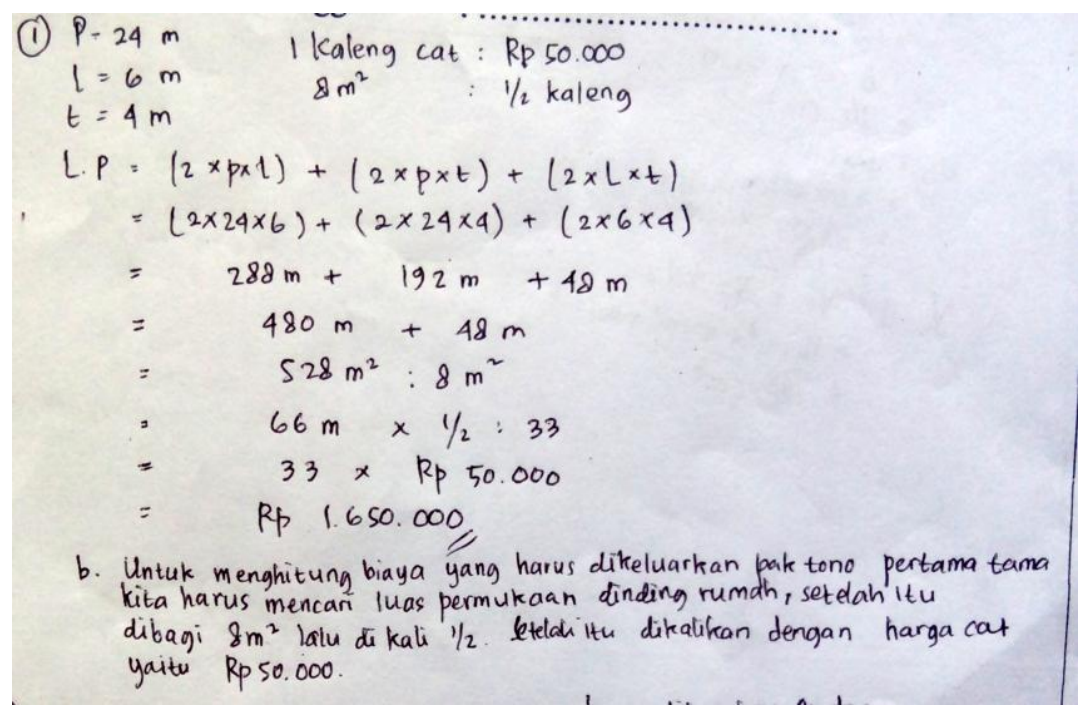

\section{Gambar 3. Jawaban S1 Soal Nomor 1}


Berdasarkan gambar 3 menunjukkan bahwa S1 telah memenuhi aspek menulis. Hal ini ditunjukkan dari kemampuan subjek dalam menuliskan semua informasi dalam soal secara lengkap. Jawaban S1 diatas juga menunjukkan subjek telah memiliki ide untuk menyelesaikan permasalahan kemudian mampu mengkomunikasikannya dengan baik secara tertulis kepada orang lain memggunakan bahasanya sendiri. Namun subjek belum mampu menyajikan model matematika yang tepat untuk menghitung luas permukaan dinding yang akan di cat.

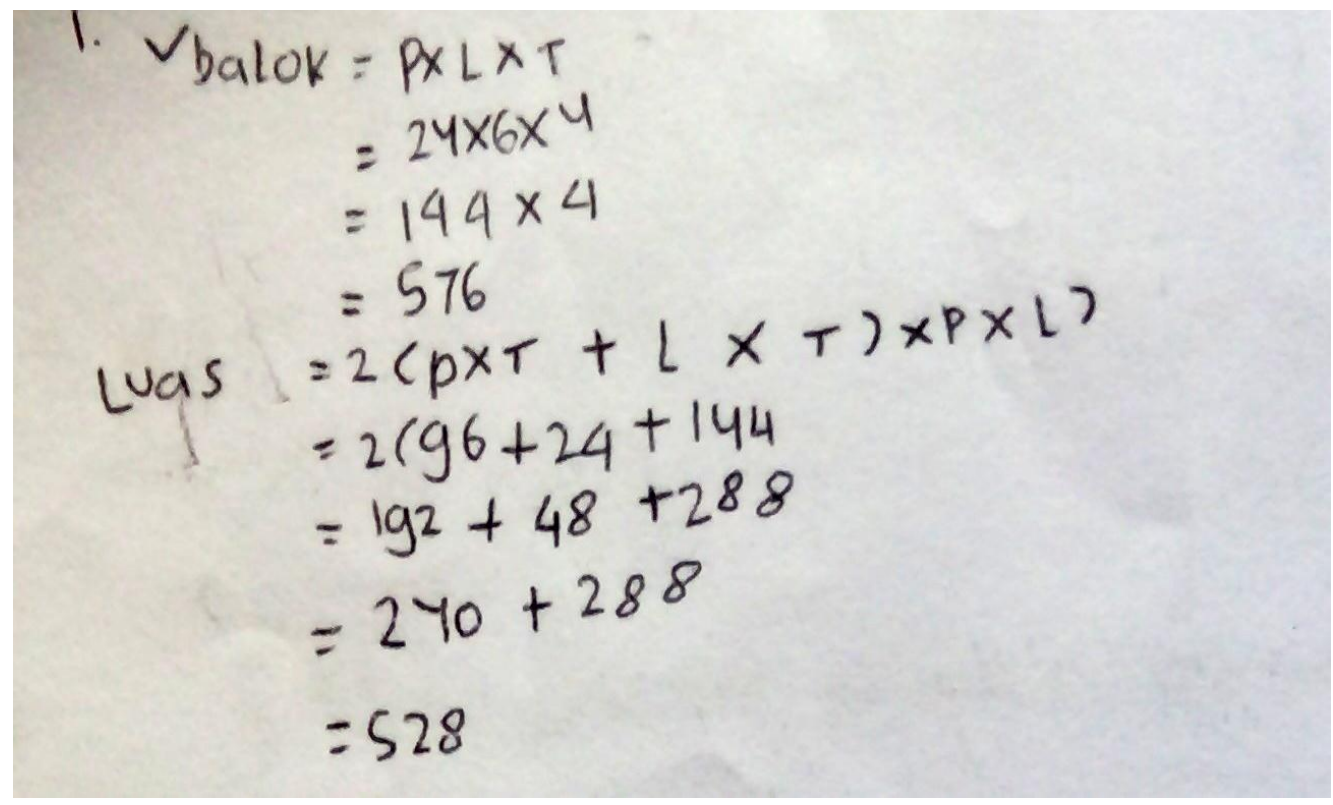

Gambar 4. Jawaban R1 soal nomor 1

Jawaban subjek R1 pada gambar 4 menunjukkan bahwa subjek sama sekali tidak mendahului jawabannya dengan menuliskan informasi-informasi yang diketahui dalam soal serta hal-hal yang ditanyakan dalam soal. Selain itu jawaban subjek R1 belum memperlihatkan kemampuan subjek dalam menjelaskan ide strategi atau solusi penyelesaian yang dimilikinya terkait dengan masalah yang disajikan dalam soal secara tertulis sesuai dengan yang diminta oleh soal. Gambar 4 menunjukkan subjek belum memahami masalah dan belum mampu menangkap ide atau solusi yang tepat sehingga subjek tidak bisa mengkomunikasikannya ke dalam ide matematika dengan benar. Hal ini terlihat dari jawaban subjek yang belum mampu memahami secara tepat kegunaan suatu rumus atau model matematika sehingga pada gambar 4 terlihat subjek menggunakan dua rumus untuk menemukan luas dinding rumah yang akan dicat. 
Pada subjek dengan kemampuan tinggi yaitu subjek T1 dan T2 sudah mampu memenuhi ketiga aspek kemampuan komunikasi matematis pada setiap soal di tiga kali siklus tes, hal ini menunjukkan bahwa subjek dengan kemampuan tinggi memiliki kemampuan komunikasi matematis yang sangat baik. Hal ini selaras dengan penelitian Ningtyas (2015) bahwa siswa dengan kemampuan tinggi telah memenuhi semua indikator komunikasi matematis diantaranya: (1) membuat situasi matematika dengan menyediakan ide dan keterangan dalam bentuk tertulis, (2) menggambarkan situasi masalah dan menyatakan solusi menggunakan gambar, dan (3) menggunakan bahasa matematika dan simbol secara tepat. Peneliti melihat perbedaan antara subjek T1 dan T2 dalam menyelesaikan soal geometri kubus dan balok. Subjek T1 lebih menunjukkan keterampilan visualisasinya dalam menyelesaikan soal, seperti menuliskan informasi ukuran panjang, lebar dan tinggi dengan menggambarkan bangun ruang tersebut secara langsung disertai dengan ukuran-ukurannya. Contoh lain terdapat pada penyelesaian soal nomor satu pada tes kedua dimana subjek T1 dapat menemukan keliling bidang sisi akuarium terkecil dengan menggambarkan bangun ruang balok terlebih dahulu kemudian dapat menyusun model matematika dari keliling bidang terkecil tersebut sedangkan subjek T2 cenderung melakukan penyelesaian soal langsung pada model matematikanya yaitu membuat model matematika semua keliling bidang sisi akuarium kemudian bisa menemukan mana bidang sisi terkecil akuarium melalui model matematikanya.

Pada subjek berkemampuan sedang yaitu S1 dari ketiga aspek yang ada, S1 lebih dominan dalam aspek menggambar hingga persentase 100\% artinya subjek S1 telah memenuhi aspek menggambar pada semua soal di tiap siklusnya. Begitu pula dengan subjek S2 yang dominan dalam memenuhi aspek menggambar dengan persentase $83.33 \%$. Sedangkan pada aspek menulis subjek S1 sudah terbiasa dengan mendahului jawabannya dengan menuliskan katerangan-keterangan pada soal hanya saja pada soal nomor 3 subjek tidak memberikan penjelasan secara tertulis mengenai beberapa strategi yang dimilikinya untuk dapat menemukan volume bangun ruang gabungan. Pada aspek ekspresi matematika, terlihat dengan jelas bahwa subjek dengan kemampuan sedang dari siklus pertama hingga siklus ketiga pemberian tes selalu mengalami kesalahan dalam menyajikan model matematika luas dinding rumah, luas permukaan bangun ruang tanpa alas ataupun luas permukaan tanpa tutup. Hal ini terjadi karena subjek kemampuan sedang belum memiliki pemahaman yang baik mengenai penurunan rumus luas permukaan balok ataupun kubus sehingga berpengaruh pada penyelesaian soal. Hal ini sejalan dengan penemuan Rosilawati 
(2018) bahwa konsep atau definisi yang didapatkan siswa pada bentuk bangun ruang bukan berasal dari hasil penemuannya sendiri, sehingga siswa cenderung belajar dengan menghafal tanpa disertai dengan pemahaman yang baik.

Subjek R1 dan R2 dengan kemampuan rendah pada siklus pertama tes hanya mampu menyelesaikan satu soal saja dengan memunculkan aspek menulis dan menggambar. Pada siklus kedua subjek R1 memunculkan aspek menggambar dan ekspresi matematika dan pada siklus ketiga tes subjek R1 hanya mampu memunculkan aspek menggambar saja sehingga R1 memenuhi aspek menggambar sebesar 50\% dan memperoleh persentase yang sangat rendah untuk aspek menulis dan ekspresi matematika. Hal yang sama dialami oleh subjek R2 dalam aspek ekspresi matematika dengan memperoleh persentase yang sangat rendah. Subjek berkemampuan rendah kesulitan dalam memahami soal dan menangkap ide dalam menyelesaikan soal sehingga belum mampu mengkomunikasikan ide apapun secara tertulis menggunakan notasi/simbol dan bahasa matematika. Selain itu subjek dengan kemampuan rendah belum sepenuhnya memahami fungsi dan kegunaan rumus volume dan luas permukaan ketika dihadapkan pada soal yang berbentuk pemecahan masalah, berbeda ketika dihadapkan pada soal yang bersifat rutin, subjek kemampuan rendah lebih mudah mengkomunikasikan ide matematisnya. Hal ini didukung oleh pernyataan Rizqi (2016) bahwa keberhasilan subjek dalam menentukan ide berpengaruh terhadap hasil penyelesaian yang diberikan.

Subjek dengan kemampuan tinggi dan sedang keduanya memiliki kesamaan dalam aspek menulis, dimana subjek mampu mengidentifikasi dan menuliskan keteranganketerangan dalam soal serta menjelaskan ide yang dimilikinya secara tertulis dengan penyampaian yang jelas dan dapat dipahami pembaca, hanya saja subjek S1 kesulitan dalam menjabarkan rumus luas permukaan balok dan kubus sehingga model matematika yang digunakan S1 belumlah sesuai dengan situasi dalam soal. Seperti pada tes siklus pertama soal nomor 1 subjek S1 belum menggunakan model matematika yang tepat untuk menghitung luas permukaan dinding dimana subjek menggunakan rumus luas permukaan balok secara utuh. Maka dapat terlihat bahwa subjek dengan kemampuan sedang hampir memiliki kemampuan yang setara dengan subjek berkemampuan tinggi, hanya saja mengalami beberapa kesulitan dalam menjelaskan ide strateginya secara tertulis dalam menyajikan model matematika yang tepat dengan situasi soal. Lutfiannisak (2018) juga menemukan hal yang sama bahwa subjek dengan kemampuan sedang dan tinggi mampu 
memenuhi standar komunikasi matematis yang sama, akan tetapi pada pelaksanaannya subjek kemampuan sedang masih kurang sempurna dan banyak kekurangan.

Pemahaman siswa akan konsep-konsep matematika tentu berawal dari proses pembelajaran di kelas, meliputi metode dan strategi mengajar guru hingga kondisi dan sikap siswa saat mengikuti proses pembelajaran. Susanto (2013) mengungkapkan bahwa pemahaman merupakan hasil dari proses pembelajaran. Selain itu menjadi salah satu faktor yang mempengaruhi kemampuan komunikasi matematis adalah pembiasaan atau pemberian soal yang memuat aspek-aspek komunikasi matematis secara rutin. Hal ini dibuktikan dengan adanya peningkatan subjek S1 dan S2 dalam menyelesaikan soal goemetri yang memuat dari pemberian tes siklus pertama hingga siklus ketiga pada aspek ekspresi matematika.

\section{KESIMPULAN}

1. Kemampuan Komunikasi matematis siswa dengan kemampuan tinggi dapat dikatakan sangat baik dari kemampuannya dalam mengkomunikasikan ide-ide matematis dengan baik ke dalam tiga aspek komunikasi matematis yaitu Aspek menulis (Written Text), aspek menggambar (Drawing) dan aspek ekspresi matematika (Mathematical Expression).

2. Kemampuan komunikasi matematis siswa dengan kemampuan sedang dominan pada dua aspek saja, yaitu Aspek menulis (Written Text) meliputi menjelaskan ide, situasi dan relasi matematika secara tulisan dan aspek menggambar (Drawing) yaitu menyatakan ide ke dalam bentuk visual, namun belum mengkomunikasikan ide matematis ke dalam ekspresi matematika dengan pemahaman yang baik.

3. Kemampuan komunikasi matematis siswa dengan kemampuan rendah dominan pada dua aspek, yaitu Aspek menulis (Written Text) meliputi menjelaskan ide, situasi dan relasi matematika secara tulisan, Aspek menggambar (Drawing) yaitu menyatakan ide ke dalam bentuk visual dan terkategorikan rendah dalam mengekspresikan ide dan gagasannya ke dalam ekspresi matematika.

4. Faktor-faktor yang mempengaruhi kemampuan komunikasi matematis tertulis siswa diantaranya proses pembelajaran, sikap dan pemahaman siswa, serta pembiasaan atau pemberian soal-soal yang dapat mengukur kemampuan komunikasi matematis secara rutin. 


\section{REFERENSI}

Hendriana, H. dkk. 2017. Hardskill dan Softskill Matematik Siswa. Bandung: PT. Refika Aditama.

Hermawati, H. 2018. Proses Pelaksanaan Remedial Teaching Terhadap Ketuntasan Belajar Matematika Peserta Didik. Skripsi pada FKIP UMMI: diterbitkan.

Hodiyanto. 2017. Kemampuan Komunikasi Matematis dalam Pembelajaran Matematika. AdmathEdu, Volume 7 Nomor 1. 9 Halaman

Lestari, K.E dan Yudhanegara M.R. (2018). Penelitian Pendidikan Matematika. Karawang: PT Refika Aditama.

Luthfiannisak dan Ummu Sholihah. 2018. Kemampuan Komunikasi Matematis Siswa dalam menyelesaikan Soal Materi Fungsi Ditinjau dari Kemampuan Matematika. Jurnal Tudris Matematika, Volume 1 Nomor 1.

Munawaroh, U. 2018. Kemampuan Komunikasi Matematis Siswa dan Faktor-faktor yang Mempengaruhinya. Skripsi Sarjana pada FKIP Universitas Muhammadiyah Ponorogo: diterbitkan.

Ningtyas, I.K. 2015. Profil Kemampuan Komunikasi Matematis Siswa Kelas VIII MTs Sultan Agung Jabalsari dalam Memahami Pokok Bahasan Garis Singgung Lingkaran Berdasarkan Kemampuan Matematika. Skripsi tidak diterbitkan, Tulungagung.

Shalihah dan Ariansyah. 2017. Analisis Kesulitan Siswa dalam Proses Pemecahan Masalah Geometri Berdasarkan Tahapan Berpikir Van Hiele. Jurnal "Mosharafa", Volume 6 Nomor 2, Halaman 287-298.

Sugiyono. 2016. Metode Penelitian Kuantitatif, Kualitatif, dan R\&D. Bandung: Alfabeta.

Susanto, A. 2013. Teori Belajar \& Pembelajaran di Sekolah Dasar (Edisi pertama). Jakarta: Prenadamedia Group

Suryana. 2010. Metode Penelitian Model Praktis Penelitian Kuantitatif dan. Kualitatif. Bandung : UPI.

Rizqi, A.A, dkk. 2016. Analisis Kemampuan Komunikasi Matematis Ditinjau dari Kepercayaan Diri Siswa Melalui Blended Learning. Unnes Journal of Mathematics Education Research. Volume 5 Nomor 1, halaman 17-23.

Rosdiana, R, dkk. 2018. Analisis Proses Berpikir Siswa SMP dalam Memecahkan Masalah Aljabar Ditinjau dari Gaya Kognitif. PYTHAGORAS. Volume 7 Nomor 2, halaman 74-84.

Rosilawati dan Alghadari. 2018 Konsepsi Siswa Pada Suatu Bentuk Bangun Ruang Terkait Dengan Rusuk dan Diagonal Sisi. Jurnal PRISMA Universitas Suryakancana. Volume 7 Nomor 2, 164-176. 